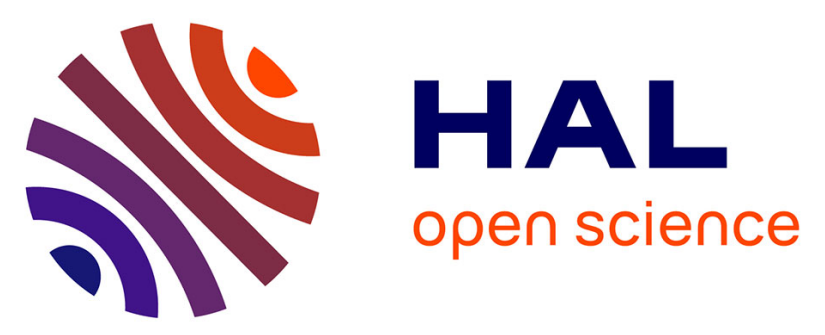

\title{
Hydroxide-Induced Degradation of Olefin Metathesis Catalysts: A Challenge for Metathesis in Alkaline Media
}

\author{
Alexandre y Goudreault, Daniel M Walden, Daniel L Nascimento, Adrian G
} Botti, Stephan N. Steinmann, Carine Michel, Deryn E Fogg

\section{- To cite this version:}

Alexandre y Goudreault, Daniel M Walden, Daniel L Nascimento, Adrian G Botti, Stephan N. Steinmann, et al.. Hydroxide-Induced Degradation of Olefin Metathesis Catalysts: A Challenge for Metathesis in Alkaline Media. ACS Catalysis, 2020, 10 (6), pp.3838-3843. 10.1021/acscatal.9b05163 . hal-02917707

\section{HAL Id: hal-02917707 \\ https://hal.science/hal-02917707}

Submitted on 19 Aug 2020

HAL is a multi-disciplinary open access archive for the deposit and dissemination of scientific research documents, whether they are published or not. The documents may come from teaching and research institutions in France or abroad, or from public or private research centers.
L'archive ouverte pluridisciplinaire HAL, est destinée au dépôt et à la diffusion de documents scientifiques de niveau recherche, publiés ou non, émanant des établissements d'enseignement et de recherche français ou étrangers, des laboratoires publics ou privés. 


\title{
Hydroxide-Induced Degradation of Olefin Metathesis Catalysts: A Chal- lenge for Metathesis in Alkaline Media
}

\author{
Alexandre Y. Goudreault, ${ }^{a}$ Daniel M. Walden, ${ }^{b}$ Daniel L. Nascimento, ${ }^{a}$ Adrian G. Botti, ${ }^{a}$ Stephan N. Stein- \\ mann, ${ }^{b}$ Carine Michel, ${ }^{* b}$ and Deryn E. Fogg ${ }^{* a}$ \\ ${ }^{a}$ Center for Catalysis Research \& Innovation, and Department of Chemistry and Biomolecular Sciences, University of Ottawa, ON, \\ Canada, K1N 6N57. ${ }^{b}$ Univ. Lyon, ENS de Lyon, CNRS UMR 5182, Université Claude Bernard Lyon 1, Laboratorie de Chimie, F- \\ 69342 Lyon, France \\ Supporting Information Placeholder
}

ABSTRACT: Hydroxide ion is shown to be a potent disruptor of Ru-catalyzed olefin metathesis, in a study of the Hoveyda catalyst HII. Addition of $\left[\mathrm{N}^{n} \mathrm{Bu}_{4}\right][\mathrm{OH}]$ immediately terminates metathesis via $\mathbf{H I I}$, an effect traced to formation of bis(hydroxide) complex HII-OH. The latter was synthesized for direct study. HII-OH initiates very slowly on reaction with olefins, and decomposes in the first cycle of metathesis. Computational analysis reveals rapid bimolecular coupling between HII-OH and its four-coordinate methylidene derivative. Importantly, fully decomposed catalyst also accelerates decomposition of HII-OH. The $\underline{H}$-bonding capacity of the hydroxide ligand is proposed as a powerful driving force for decomposition.

Keywords. olefin metathesis, catalyst decomposition, N-heterocyclic carbene, water, aqueous metathesis, hydrogen-bonding, chemical biology

Ruthenium-catalyzed olefin metathesis offers exceptionally powerful methodologies for the assembly of carbon-carbon bonds. ${ }^{1}$ In many applications in total synthesis, ${ }^{2,3}$ pharmaceutical manufacturing, ${ }^{4}$ and chemical biology, ${ }^{5-7}$ metathesis is carried out on densely-functionalized substrates bearing polar functional groups, in the presence of variable amounts of water. We speculated that hydroxide ion might pose a common, unrecognized challenge to catalyst function under such conditions. At the extreme is the metathetical modification of proteins in water buffered to $\mathrm{pH}>7$, a forefront application that necessitates use of the $\mathrm{Ru}$ complex in high stoichiometric excess. ${ }^{6}$ While clever strategies have been designed to accelerate metathesis relative to catalyst degradation, ${ }^{7}$ the basis of the problem remains ambiguous. Understanding the unintended, non-metathetical reactivity of the $\mathrm{Ru}=\mathrm{CHR}$ bond under such conditions is thus of both fundamental and practical importance. The present work was aimed at assessing the impact of hydroxide on the productivity and fate of the second-generation Hoveyda catalyst HII, an exemplary, widely used metathesis catalyst.

Prominent among the decomposition pathways now known to disrupt $\mathrm{Ru}$-catalyzed metathesis are those enabled by nucleophiles and Bronsted base (Scheme 1). Nucleophiles have been shown to attack the methylidene carbon of Ru$\mathbf{1}{ }^{8,9}$ while Bronsted bases readily deprotonate the metallacyclobutane (MCB) intermediate $\mathbf{R u - 2} .^{10,11}$ The potential engagement of hydroxide ion in either manifold was antici- pated. ${ }^{12-14}$ Unexpectedly, however, a potent new decomposition pathway was identified, which appears unique to $\mathrm{Ru}$ hydroxide species. Here we describe transformation of HII into bis-hydroxide complex HII-OH, and bimolecular decomposition of HII-OH during the first cycle of metathesis.

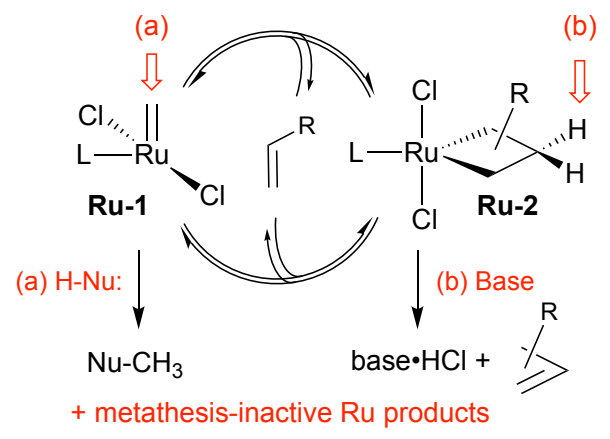

Scheme 1. Decomposition of Metathesis-Active Species by (a) Nucleophiles; (b) Bronsted Base. L $=\mathrm{H}_{2}$ IMes; Red Arrows Indicate Sites of Attack.

Our attention was first drawn to the potential of hydroxide ion to hinder metathesis in studies of the impact of Bronsted base on metathesis productivity. ${ }^{10,15}$ Yields were negatively affected by the presence of strongly basic enolate anions, ${ }^{10}$ but dropped even further when water was added as a sacrificial proton source. ${ }^{15}$ (In contrast, sacrifical phenols restored metathesis activity). Likewise suggestive was a preliminary survey of the impact of common contaminants on metathesis 
productivity. These experiments examined the impact of additives on turnover numbers (TON) in cyclization of diethyl diallylmalonate (DDM, A; Figure 1), with the rationale that any agents capable of disrupting this exceptionally facile ring-closing metathesis (RCM) reaction merit attention. As shown in Figure 1a, either water or morpholine C (a basic contaminant present in technical grade toluene) ${ }^{16}$ caused TONs to drop by approximately half, but a 50\% further decrease occurred when both water and morpholine were present.

The premise that hydroxide ion might be responsible was tested via a knockdown experiment, in which $\left[\mathrm{N}^{n} \mathrm{Bu}_{4}\right][\mathrm{OH}]$ (a THF-soluble source of hydroxide ion) ${ }^{17}$ was added during RCM. Metathesis activity immediately ceased (Figure 1b; red line), even at catalyst loadings $20 \mathrm{x}$ higher than those used in the original screen. To assess whether this drop reflects attack on the active species $R \mathbf{u}-\mathbf{1}$ or $\mathbf{R u - 2}$, or on the precatalyst HII, a second experiment was carried out, in which hydroxide was added prior to substrate. RCM activity (blue line) was completely suppressed. This suggests that hydroxide ion attacks HII to yield a ruthenium product that is either completely inactive, or decomposes in the first cycle of metathesis.

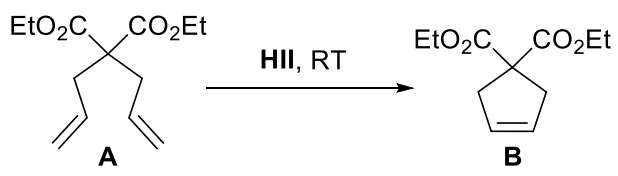

(a) $0.005 \mathrm{~mol} \% \mathrm{HII}, \mathrm{C}_{7} \mathrm{H}_{8}, 4 \mathrm{~h}$.

(b) $0.1 \mathrm{~mol} \% \mathrm{HII}, \mathrm{C}_{6} \mathrm{H}_{6}, 1 \mathrm{~h}$.
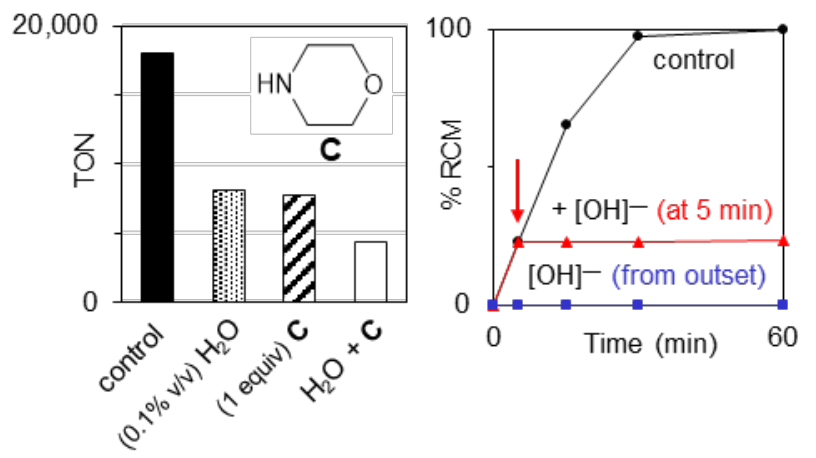

Figure 1. Impact of additives on RCM. (a) Water, morpholine C, or both. (b) $\left[\mathrm{N}^{n} \mathrm{Bu}_{4}\right][\mathrm{OH}]$ (2 equiv vs $\left.\mathrm{Ru}\right)$.

Synthesis of the putative hydroxide complex was undertaken for closer examination. Accordingly, aqueous $\left[\mathrm{N}^{n} \mathrm{Bu}_{4}\right][\mathrm{OH}]$ was added to a solution of HII in THF (Scheme 2). ${ }^{18}$ As use of 1 equiv hydroxide per $\mathrm{Ru}$ resulted in $50 \%$ consumption of HII, a 2:1 stoichiometry was employed. A colour change from green to red occurred over the time of mixing, and ${ }^{1} \mathrm{H}$ NMR analysis revealed a new singlet for the benzylidene proton at $14.04 \mathrm{ppm}$ (cf. $16.72 \mathrm{ppm}$ for HII). Reaction was complete in $<10 \mathrm{~min}$ even on $200 \mathrm{mg}$ scale, and bishydroxide HII-OH was isolated in ca. $85 \%$ yield. Complete selectivity for salt metathesis was evident, as expected from reactions of related $\mathrm{Ru}$ alkylidenes with aryloxide ion, ${ }^{19}$ but in contrast with reactions of hydroxide with $\mathrm{Ru}-\mathrm{CO}$ complexes, which yield $\mathrm{Ru}$ formates via attack on the carbonyl ligand. ${ }^{12 a, b}$

With the exception of the Ru=CHAr signal, the chemical shifts and multiplicities of all proton signals for HII-OH accord closely with those for HII. An additional singlet was observed for the $\mathrm{Ru}-\mathrm{OH}$ protons at $1.1 \mathrm{ppm}$, the assignment of which was confirmed by exchange with degassed $\mathrm{D}_{2} \mathrm{O} .{ }^{20}$ The structure depicted for HII-OH in Scheme 2 is that predicted by density functional theory (DFT) analysis: specifically, a distorted trigonal bipyramidal geometry, ${ }^{21}$ with an $\mathrm{HO}-\mathrm{Ru}-\mathrm{OH}$ angle of $139.1^{\circ}$ (Table S2). In comparison, the $\mathrm{Cl}-\mathrm{Ru}-\mathrm{Cl}$ angle for $\mathrm{HII}$ is nearly $20^{\circ}$ larger (computed: $155.1^{\circ}$; crystallographic: $\left.:^{22} 156.5^{\circ}\right)$.

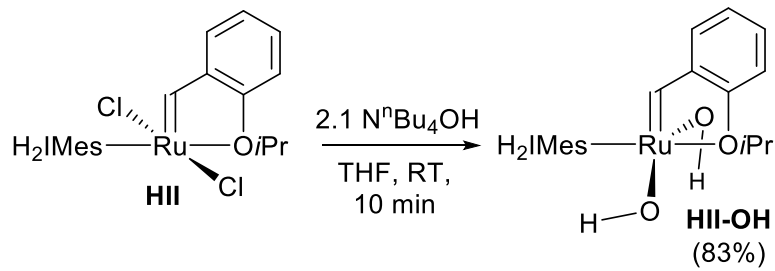

Scheme 2. Synthesis of HII-OH.

Consistent with the knockdown behaviour seen in Figure 1b, HII-OH proved unreactive toward DDM. Even with 10 mol\% of HII-OH at $60{ }^{\circ} \mathrm{C},<3 \%$ RCM was evident after $2 \mathrm{~h}$ (cf. $100 \%$ within $15 \mathrm{~min}$ at RT with $1 \mathrm{~mol} \%$ HII as catalyst). Slow initiation of HII-OH is not surprising, given the inductive withdrawal of electron density from the Ru center by the oxygen ligands. The compressed $\mathrm{HO}-\mathrm{Ru}-\mathrm{OH}$ angle may also be relevant, as $\mathrm{Ru}$ metathesis catalysts with cis-anionic geometries are known to initiate very slowly. ${ }^{23}$

Computational analysis of the initiation step, undertaken using ethylene as a model olefin (Scheme S4a), ${ }^{24}$ revealed a higher energy barrier to cycloaddition for HII-OH, relative to HII $(20.9 \mathrm{kcal} / \mathrm{mol}$, vs. $16.7 \mathrm{kcal} / \mathrm{mol})$. The resulting metallacyclobutane is trigonal bipyramidal in both cases, but intramolecular H-bonding of the $\mathrm{OH}$ ligands (ca. $2 \AA$ ) stabilizes a cis-anionic geometry for HII-OH, in contrast with the trans-anionic geometry seen for HII (Scheme S4b).

While this energy difference accounts for slower reaction of HII-OH, it does not account for the complete loss of metathesis activity. We infer that HII-OH is considerably more susceptible to decomposition. In examining the relevant pathways, we first considered those established for HII and related catalysts (see Introduction). Nucleophilic attack by hydroxide on the benzylidene carbon (cf. Scheme 1a) is expected to liberate the aldehyde $\mathrm{HC}(\mathrm{O}) \mathrm{Ar}\left(\mathrm{Ar}=o-\mathrm{C}_{6} \mathrm{H}_{4}\right.$ $\left.\mathrm{O}^{i} \mathrm{Pr}\right){ }^{25}$ This aldehyde is indeed detected, but in minor, variable amounts, depending on rates of mixing. ${ }^{26}$ The alternative possibility, in which a hydroxide ligand deprotonates the MCB Ru-3 (cf. Scheme 1b), is unlikely given the ca. 41 $\mathrm{kcal} / \mathrm{mol}$ barrier calculated by DFT analysis (Scheme S5). A potent new decomposition pathway thus appears to be 
operative. Given that the sole difference between HII and HII$\mathbf{O H}$ lies in the nature of the anionic ligands (and given that related $\mathrm{Ru}(\mathrm{OAr})_{2}$ and $\mathrm{Ru}\left(\kappa^{2}-\mathrm{O}_{2} \mathrm{C}_{6} \mathrm{R}_{4}\right)$ exhibit notably high metathesis productivity), ${ }^{19}$ the hydroxide groups appears to play a critical, negative role.

To gain deeper insight, we reacted HII-OH with ethylene, using a sealed NMR tube to retain any volatile products (Scheme 3). Loss of the $[\mathrm{Ru}]=\mathrm{CHAr}$ signal for HII-OH was complete within $24 \mathrm{~h}$. Unexpectedly, however, only ca. $50 \%$ of the HII-OH complex had participated in metathesis, as judged from the combined yields of styrenyl ether $\mathbf{D}$ (Scheme 3a) and propenes E/E' (Scheme 3b). These propenes are presumed to form via $\beta$-elimination from the MCB Ru-3, a well-established decomposition pathway for $\mathbf{H I I}^{27,28}$ and other metathesis catalysts. ${ }^{29}$ The computed barrier to elimination of $\mathbf{E} / \mathbf{E}$ ' from $\mathbf{R u - 3}$ is comparable to that for cycloreversion ( 15.9 vs. $17.0 \mathrm{kcal} / \mathrm{mol}$, respectively).

The fact that these organic products account for only $50 \%$ of the starting $\mathbf{H I I}-\mathbf{O H}$ is puzzling. As $\mathrm{Ru}(\mathrm{OH})$ complexes are known to form hydroxy-bridged dimers with remarkable facility, ${ }^{30,31}$ we queried whether bimolecular coupling might consume HII-OH prior to metathesis. We recently reported that HII and related metathesis catalysts decompose via dimerization of $\mathrm{RuCl}_{2}\left(\mathrm{H}_{2} \mathrm{IMes}\right)\left(=\mathrm{CH}_{2}\right)$, Ru-1. ${ }^{29}$ In the case of HII-OH, slow initiation limits the concentration of the corresponding hydroxo complex Ru-4. This disfavours homo-coupling of two Ru-4 molecules, but opens the door to hetero-coupling with the large excess of HII-OH present (Figure 2, bottom). Trapping of HII-OH upon formation of Ru-4 could account for the engagement of only 50\% HIIOH in metathesis. ${ }^{32}$

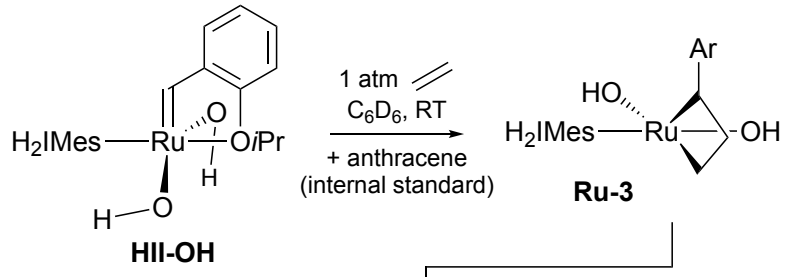

(a) metathesis exchange $(40 \%)+$

(b) MCB decomposition (8\%)<smiles>[R14][14C](=C)[14C](C)(O)O</smiles><smiles>[R15][R1](O)(O)[AsH2]</smiles>

$\mathrm{Ar}=\mathrm{O}-\mathrm{C}_{6} \mathrm{H}_{4} \mathrm{O}^{i} \mathrm{Pr}$

Scheme 3. Products Generated in the First Cycle of Metathesis. (a) Via Metathesis Exchange. (b) Via MCB Decomposition. ${ }^{a}$

${ }^{a}$ Path (a) is quantified from the yield of $\mathbf{D}$; Path (b) from the yield of $\mathbf{E}+\mathbf{E}^{\prime}$ ( $4 \%$ each).

DFT calculations indicate that hetero-coupling of HII-OH is indeed thermodynamically favoured relative to ethylene binding. The latter is endergonic by $13.3 \mathrm{kcal} / \mathrm{mol}$. Because these calculations are based on gas-phase entropies, however, they greatly exaggerate the entropic penalty to dimerization. If we adopt one proposed correction factor, and add $50 \%$ of the gas-phase entropy to account for the change from perfect gas to perfect solution, ${ }^{33}$ the heterodimer is $-12.4 \mathrm{kcal} / \mathrm{mol}$ more stable than HII-OH + Ru-4, whereas the ethylene complex lies at $+14.9 \mathrm{kcal} / \mathrm{mol}$. Hetero-dimerization is thus greatly favoured relative to ethylene binding (the requisite first step for formation of $\mathbf{D}$ and Ru-4). Consistent with this picture, kinetics experiments indicate that decomposition is first order in [Ru] (Figure S2). That is, formation of $\mathbf{R u - 4}$ is rate-limiting.

Two conformers of the anticipated ${ }^{29,34,35}$ heterodimer are predicted to be thermodynamically favoured with respect to HII-OH + Ru-4. These are transoid- and cisoid-Ru-6, of which the former is the more stable $(\Delta G-4.0 \mathrm{kcal} / \mathrm{mol})$. Liberation of styrenyl ether $\mathbf{D}$ from transoid-Ru-6 is inhibited by the relative disposition of the two ylidene groups on opposite sides of the $\mathrm{Ru}_{2}(\mu-\mathrm{OH})_{2}$ plane. Precedents from the chloride system $^{29}$ suggest that elimination of $\mathbf{D}$ from cisoid-Ru-6 could be feasible, if the methylidene ligand can adopt the conformation shown in cisoid-Ru-6' (inset, Figure 2 ). However, the proportion of $\mathbf{D}$ liberated via the sum of metathesis and decomposition should then approach $100 \%$. The observed $40 \%$ yield of $\mathbf{D}$ argues against such an elimination pathway. Instead, the cumulative data suggest that while bimolecular coupling is thermodynamically favoured relative to metathesis, $\mathrm{C}=\mathrm{C}$ coupling and elimination is inhibited.

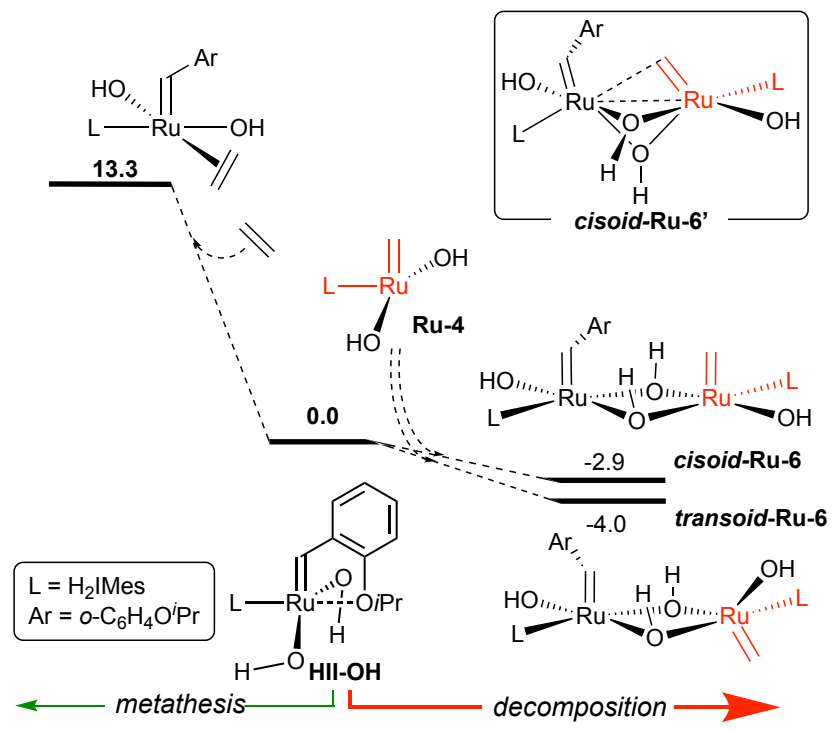

Figure 2. Competing reaction pathways for HII-OH: ethylene binding, vs. hetero-coupling with Ru-4. Gibbs free energies $(\mathrm{kcal} / \mathrm{mol})$ computed at the PBE-D3M(BJ)/ccpVQZ+ECP28MDF/PCM(Benzene) // M06L/ccpVDZ+ECP28MDF) level of theory. The free energy for the heterodimer is underestimated, owing to exaggeration of the entropic penalty to dimerization: see text. 
To confirm that decomposed $\mathrm{Ru}-\mathrm{OH}$ species can trap $\mathbf{H I I}-\mathbf{O H}$, we added fresh catalyst to a solution of the decomposed material (Figure 3). Disappearance of the fresh HII-OH was indeed much faster than in the control reaction of HII-OH under $\mathrm{N}_{2}$. (As expected, however, it is slower than decomposition of HIIOH under ethylene). Importantly, the corresponding experiment with HII caused negligible decomposition of fresh HII (Figure S3). The H-bonding capacity of the hydroxide ligands thus appears to be critical in promoting attack of decomposed $\mathrm{Ru}-\mathrm{OH}$ species on fresh catalyst.

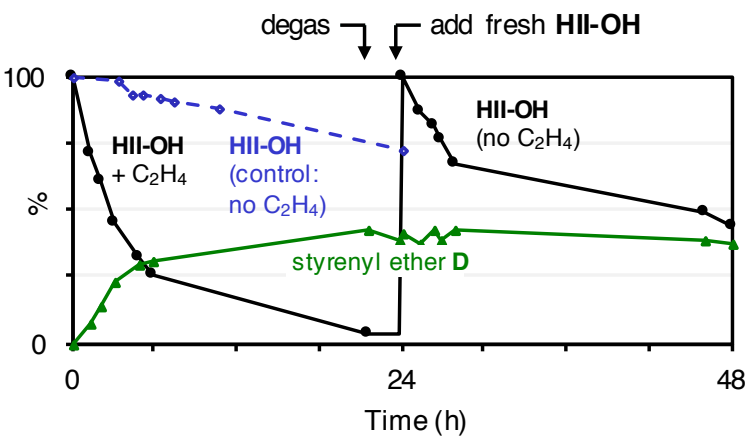

Figure 3. Accelerating effect of decomposed catalyst on the decomposition of HII-OH. Black: (left) Decomposition of HIIOH under $\mathrm{C}_{2} \mathrm{H}_{4}$; (right) impact of decomposed HII-OH on fresh precatalyst. Green: proportion of $\mathbf{D}$ formed during experiments indicated with black lines).

While coupling of HII-OH with Ru-4 is thus plausible, we were unable to detect the alkylidene protons of Ru-6 by NMR analysis, or to observe agglomerated species by DOSY-NMR. This, as well as the steady degradation in NMR signal-to-noise ratios over the $24 \mathrm{~h}$ timescale of decomposition (Figure S11) is consistent with rapid transformation of Ru-6 into paramagnetic products. Paramagnetism may result from the versatile coordination modes and redox properties of the hydroxide ligand, ${ }^{30,31}$ although multisite alkylidene binding is also feasible. ${ }^{36,37}$

The foregoing demonstrates that hydroxide ion is an unexpectedly potent disruptor of $\mathrm{Ru}$-catalyzed olefin metathesis. Termination is traced to the slow initiation and rapid decomposition of the bis(hydroxide) complex HII-OH. A notable feature is the capacity of the decomposed $\mathrm{Ru}$ species to sequester and decompose the precatalyst HII-OH, behaviour that arises from the H-bonding capacity of the hydroxide ligand. These results highlight previously unrecognized challenges to metathesis under conditions that can generate hydroxide, and more particularly metathesis in alkaline water.

\section{ASSOCIATED CONTENT}

The Supporting Information is available free of charge on the ACS Publications website.

PDF file: experimental and computational details, NMR spectra xyz files: computed xyz coordinates and energies

\section{AUTHOR INFORMATION}

Corresponding Authors

*dfogg@uottawa.ca, carine.michel@ens-lyon.fr

\section{ACKNOWLEDGMENT}

The University of Ottawa, CNRS, and ENS Lyon are thanked for support via the International Associated Laboratory 'Fundamental Catalysis for Green Chemistry' (FUNCAT). The Natural Sciences and Engineering Research Council of Canada (NSERC), the SYSPROD project and AXELERA Pôle de Compétitivité for financial support (PSMN Data Center) are thanked for financial support.

\section{REFERENCES}

(1) (a) Grela, K., Olefin Metathesis-Theory and Practice. Wiley: Hoboken, NJ, 2014. (b) Grubbs, R. H.; Wenzel, A. G., Handbook of Metathesis. 2nd ed.; Wiley-VCH: Weinheim, 2015.

(2) Cossy, J.; Arseniyadis, S.; Meyer, C., Metathesis in Natural Product Synthesis: Strategies, Substrates and Catalysts. Wiley-VCH: Weinheim, 2010.

(3) Furstner, A., Metathesis in Total Synthesis. Chem. Commun. 2011, 47, 6505-6511.

(4) (a) Higman, C. S.; Lummiss, J. A. M.; Fogg, D. E. Olefin Metathesis at the Dawn of Uptake in Pharmaceutical and Specialty Chemicals Manufacturing. Angew. Chem., Int. Ed. 2016, 55, 3552-3565. (b) Fandrick, K. R.; Savoie, J.; Jinhua, N. Y.; Song, J. J.; Senanayake, C. H., Challenges and Opportunities for Scaling the Ring-Closing Metathesis Reaction in the Pharmaceutical Industry. In Olefin Metathesis - Theory and Practice, Grela, K., Ed. Wiley: Hoboken, 2014; pp 349-366. (c) Farina, V.; Horváth, A., Ring-Closing Metathesis in the Large-Scale Synthesis of Pharmaceuticals. In Handbook of Metathesis, Grubbs, R. H.; Wenzel, A. G., Eds. Wiley-VCH: Weinheim, 2015; Vol. 2, pp 633-658.

(5) For selected recent examples, see: (a) Bhushan, B.; Lin, Y. A.; Bak, M.; Phanumartwiwath, A.; Yang, N.; Bilyard, M. K.; Tanaka, T.; Hudson, K. L.; Lercher, L.; Stegmann, M.; Mohammed, S.; Davis, B. G., Genetic Incorporation of Olefin Cross-Metathesis Reaction Tags for Protein Modification. J. Am. Chem. Soc. 2018, 140, 14599-14603. (b) Lu, X.; Fan, L.; Phelps, C. B.; Davie, C. P.; Donahue, C. P., Ruthenium Promoted On-DNA Ring-Closing Metathesis and Cross-Metathesis. Bioconjugate Chem. 2017, 28, 1625-1629. (c) Grison, C. M.; Burslem, G. M.; Miles, J. A.; Pilsl, L. K. A.; Yeo, D. J.; Imani, Z.; Warriner, S. L.; Webb, M. E.; Wilson, A. J., Double Quick, Double Click Reversible Peptide "Stapling". Chem. Sci. 2017, 8, 5166-5171. (d) Cromm, P. M.; Spiegel, J.; Kuchler, P.; Dietrich, L.; Kriegesmann, J.; Wendt, M.; Goody, R. S.; Waldmann, H.; Grossmann, T. N., Protease-Resistant and Cell-Permeable Double-Stapled Peptides Targeting the Rab8a GTPase. ACS Chem. Biol. 2016, 11, 2375-2382. For recent and seminal early reviews, see: (e) Vinogradova, E. V., Organometallic Chemical Biology: An Organometallic Approach to Bioconjugation. Pure Appl. Chem. 2017, 89, 1619-1640. (f) Chalker, J. M.; Bernardes, G. J. L.; Lin, Y. A.; Davis, B. G., Chemical Modification of Proteins at Cysteine: Opportunities in Chemistry and Biology. Chem. - Asian J. 2009, 4, 630-640. (g) Binder, J. B.; Raines, R. T., Olefin Metathesis for Chemical Biology. Curr. Opin. Chem. Biol. 2008, 12, 767-773. See also refs 6, 7.

(6) Isenegger, P. G.; Davis, B. G., Concepts of Catalysis in SiteSelective Protein Modifications. J. Am. Chem. Soc. 2019, 141, 8005-8013.

(7) Lin, Y. A.; Davis, B. G., The Allylic Chalcogen Effect in Olefin Metathesis. Beilstein J. Org. Chem. 2010, 6, 1219-1228.

(8) Nucleophilic amines can abstract the alkylidene ligand, as shown in Scheme 1a: (a) Lummiss, J. A. M.; Botti, A. G. G.; Fogg, D. E., Isotopic Probes for Ruthenium-Catalyzed Olefin Metathesis. Catal. Sci. Technol. 2014, 4, 4210-4218. (b) Lummiss, J. A. M.; Ireland, B. J.; Sommers, J. M.; Fogg, D. E., Amine-Mediated Degradation in Olefin Metathesis Reactions that Employ the Second-Generation Grubbs Catalysts. Chem CatChem 2014, 6, 459-463. For nucleophilic attack of a 
free carbene at a methylidene carbon, see: (c) Rufh, S.; Goudreault, A. Y.; Foscato, M.; Jensen, V. R.; Fogg, D. E., Rapid Decomposition of Olefin Metathesis Catalysts by a Truncated N-Heterocyclic Carbene (NHC): Unprecedentedly Efficient Catalyst Quenching and NHC Vinylation ACS Catal. 2018, 8, 11822-11826.

(9) Nucleophilic phosphines can likewise abstract the $[\mathrm{Ru}]=\mathrm{CHR}$ carbon. For a mechanistic study demonstrating this pathway for broad range of $\mathrm{PR}_{3}$-stabilized benzylidene and indenylidene metathesis precatalysts, see: (a) McClennan, W. L.; Rufh, S. A.; Lummiss, J. A. M.; Fogg, D. E., A General Decomposition Pathway for Phosphine-Stabilized Metathesis Catalysts: Lewis Donors Accelerate Methylidene Abstraction. J. Am. Chem. Soc. 2016, 138, 14668-14677. For isolation of the $[\mathrm{Ru}]-$ $\mathrm{CH}_{2} \mathrm{PCy}_{3}$ intermediate in the first-generation Grubbs system, see: (b) Lummiss, J. A. M.; McClennan, W. L.; McDonald, R.; Fogg, D. E., DonorInduced Decomposition of the Grubbs Catalysts: An Intercepted Intermediate Organometallics 2014, 33, 6738-6741. For the key observation of $\left[\mathrm{MePCy}_{3}\right] \mathrm{Cl}$, see: (c) Hong, S. H.; Wenzel, A. G.; Salguero, T. T.; Day, M. W.; Grubbs, R. H., Decomposition of Ruthenium Olefin Metathesis Catalysts. J. Am. Chem. Soc. 2007, 129, 7961-7968. For elimination of the corresponding ylid, see: (d) Galan, B. R.; Pitak, M.; Keister, J. B.; Diver, S. T., Isocyanide-Promoted Ylidene Transfer to Phosphorus: Rearrangement in the First-Generation Grubbs Complex. Organometallics 2008, 27, 3630-3632. For other examples, see: (e) Werner, H.; Stuer, W.; Weberndorfer, B.; Wolf, J., Hydrido(carbonyl) and Hydrido(carbene) Complexes of Ruthenium. Eur. J. Inorg. Chem. 1999, 1707-1713. (f) Hansen, S. M.; Rominger, F.; Metz, M.; Hofmann, P., The First Grubbs-Type Metathesis Catalyst with Cis Stereochemistry: Synthesis of $\left(\eta^{2}-\mathrm{dtbpm}\right) \mathrm{RuCl}_{2}\left(=\mathrm{CHCH}=\mathrm{CMe}_{2}\right)$ From a Novel, Coordinatively Unsaturated Dinuclear Ruthenium Dihydride. Chem. - Eur. J. 1999, 5, 557-566.

(10) Bailey, G. A.; Lummiss, J. A. M.; Foscato, M.; Occhipinti, G.; McDonald, R.; Jensen, V. R.; Fogg, D. E., Decomposition of Olefin Metathesis Catalysts by Brønsted Base: Metallacyclobutane Deprotonation as a Primary Deactivating Event. J. Am. Chem. Soc. 2017, 139, $16446-$ 16449.

(11) Ireland, B. J.; Dobigny, B. T.; Fogg, D. E., Decomposition of a Phosphine-Free Metathesis Catalyst by Amines and Other Nitrogen Bases: Metallacyclobutane Deprotonation as a Major Deactivation Pathway. ACS Catal. 2015, 5, 4690-4698.

(12) Precedents for nucleophilic attack by hydroxide ion on ligands at $\mathrm{Ru}$ centres are found in contexts ranging from the water-gas shift reaction (WGSR) in aqueous alkaline media, to catalyst synthesis, to water oxidation catalysis. Selected examples: (a) Sinha, A.; Ghatak, T.; Bera, J. K., Hydroxycarbonyl Complexes as Key Intermediates in the Base-Assisted Reduction of Ruthenium Carbonyls. Dalton Trans. 2010, 39, 1130111313. (b) Sentets, S.; Rodriguez Martinez, M. d. C.; Vendier, L.; Donnadieu, B.; Huc, V.; Lugan, N.; Lavigne, G., Instant "Base-Promoted" Generation of Roper's-type $\mathrm{Ru}(0)$ Complexes $\mathrm{Ru}(\mathrm{CO})_{2}\left(\mathrm{PR}_{3}\right)_{3}$ from a Simple Carbonylchlororuthenium(II) Precursor. J. Am. Chem. Soc. 2005, 127, 14554-14555. (c) Wang, Y.; Zhan, S.; Ahlquist, M. S. G., Nucleophilic Attack by $\mathrm{OH}_{2}$ or $\mathrm{OH}^{-}$: A Detailed Investigation on $\mathrm{pH}$-Dependent Performance of a Ru Catalyst. Organometallics 2019, 38, 1264-1268.

(13) An important difference should be noted between decomposition by hydroxide itself, vs. hydroxide in methanol (a medium once widely used for metathesis in biologically-relevant contexts, the impact of which was discussed in: (a) Camm, K. D.; Fogg, D. E., From Drug Cocktails to Tissue Engineering: Synthesis of ROMP Polymers for Biological Applications. In NATO Sci. Ser. II, Imamoglu, Y.; Dragutan, V., Eds. Springer Verlag: Berlin, 2007; Vol. 243, pp 285-303). The latter conditions convert the catalysts to methoxide complexes, which decompose to $\mathrm{Ru}$ hydrides via $\beta$-elimination. See: (b) Beach, N. J.; Lummiss, J. A. M.; Bates, J. M.; Fogg, D. E., Reactions of Grubbs Catalysts with Excess Methoxide: Formation of Novel Methoxyhydride Complexes. Organometallics 2012, 31, 2349-2356. (c) Dinger, M. B.; Mol, J. C., Degradation of the First-Generation Grubbs Metathesis Catalyst with Primary Alcohols, Water, and Oxygen. Formation and Catalytic Activity of Ruthenium(II) Monocarbonyl Species. Organometallics 2003, 22, 1089 1095. For exploitation of this effect in tandem catalysis, see: (d) Schmidt,
B., In situ Conversion of a $\mathrm{Ru}$ Metathesis Catalyst to an Isomerization Catalyst. Chem. Commun. 2004, 742-743.

(14) As noted by a referee, exchange of chloride for fluoride also has a deactivating effect, which can be countered by addition of (TMS $)_{2} \mathrm{O}$ to remove fluoride anions. See: Osman, S.; Koide, K., Ruthenium-Catalyzed Olefin Metathesis after Tetra-N-Butylammonium Fluoride-Mediated Desilylation. Tetrahedron Letters 2012, 53, 6637-6640.

(15) Santos, A. G.; Bailey, G. A.; dos Santos, E. N.; Fogg, D. E., Overcoming Catalyst Decomposition in Acrylate Metathesis: Poly-phenol Resins as Enabling Agents for Phosphine-Stabilized Metathe-sis Catalysts. ACS Catal. 2017, 7, 3181-3189.

(16) Nicola, T.; Brenner, M.; Donsbach, K.; Kreye, P., First Scale-Up to Production Scale of a Ring Closing Metathesis Reaction Forming a 15Membered Macrocycle as a Precursor of an Active Pharmaceutical Ingredient. Org. Process Res. Dev. 2005, 9, 513-515.

(17) The $\left[\mathrm{N}^{n} \mathrm{Bu}_{4}\right][\mathrm{OH}]$ reagent was employed as a solution in degassed water, rather than as its alternative formulation as a solution in methanol, to circumvent formation of methoxide derivatives which rapidly decompose via $\beta$-elimination. See: (a) Beach, N. J.; Lummiss, J. A. M.; Bates, J. M.; Fogg, D. E., Reactions of Grubbs Catalysts with Excess Methoxide: Formation of Novel Methoxyhydride Complexes. Organometallics 2012, 31, 2349-2356. (b) Dinger, M. B.; Mol, J. C., Degradation of the First-Generation Grubbs Metathesis Catalyst with Primary Alcohols, Water, and Oxygen. Formation and Catalytic Activity of Ruthenium(II) Monocarbonyl Species. Organometallics 2003, 22, 10891095.

(18) The ammonium salt was used, as reaction with excess $\mathrm{KOH}$ yielded an equilibrium mixture. Similar behaviour was reported in salt metathesis with $\mathrm{KBr}$ and KI. See: J. Wappel, C. A. Urbina-Blanco, M. Abbas, J. H. Albering, R. Saf, S. P. Nolan, C. Slugovc, Halide Exchanged Hoveyda-Type Complexes in Olefin Metathesis. Beilstein J. Org. Chem. 2010, 6, 1091-1098.

(19) Catecholates, $\mathrm{O}_{2} \mathrm{C}_{6} \mathrm{X}_{4}(\mathrm{X}=\mathrm{H}, \mathrm{F}, \mathrm{Cl}, \mathrm{Br})$ : (a) Monfette, S.; Camm, K. D.; Gorelsky, S. I.; Fogg, D. E., Electronic Effects of the Anionic Ligand in Ruthenium-Catalyzed Olefin Metathesis. Organometallics 2009, 28, 944-946. (b) Monfette, S.; Fogg, D. E., Ruthenium Metathesis Catalysts Containing Chelating Aryloxide Ligands. Organometallics 2006, 25, 1940-1944. Perfluoroaryloxide, $\mathrm{OC}_{6} \mathrm{~F}_{5}$ : (c) Conrad, J. C.; Amoroso, D.; Czechura, P.; Yap, G. P. A.; Fogg, D. E., The First Highly Active, Halide-Free Ruthenium Catalyst for Olefin Metathesis. Organometallics 2003, 22, 3634-3636. (d) Conrad, J. C.; Parnas, H. H.; Snelgrove, J. L.; Fogg, D. E., Highly Efficient Ru-Pseudohalide Catalysts for Olefin Metathesis. J. Am. Chem. Soc. 2005, 127, 11882-11883.

(20) For detailed characterization data, see SI.

(21) Tau parameter analysis reveals a distorted trigonal bipyramidal geometry for Ru-1, as compared to distorted square pyramidal for HII ( tau $=0.61$ or 0.39 , respectively; cf. values of 0 for a perfect square pyramid, and 1 for a perfect trigonal bipyramid). See: Addison, A. W.; Rao, T. N.; Reedijk, J.; Van Rijn, J.; Verschoor, G. C., Synthesis, Structure, and Spectroscopic Properties of Copper(II) Compounds Containing NitrogenSulfur Donor Ligands. J. Chem. Soc., Dalton Trans. 1984, 1349-1356.

(22) Garber, S. B.; Kingsbury, J. S.; Gray, B. L.; Hoveyda, A. H., Efficient and Recyclable Monomeric and Dendritic Ru-Based Metathesis Catalysts. J. Am. Chem. Soc. 2000, 122, 8168-8179.

(23) For an explicit discussion, see: (a) Kotyk, M. W.; Gorelsky, S. I.; Conrad, J. C.; Carra, C.; Fogg, D. E., Geometric and Electronic Structure of a $\mathrm{C}_{1}$-Symmetric Ru-Aryloxide Metathesis Catalyst: An Experimental and Computational Study. Organometallics 2009, 28, 5424-5431. For early experimental evidence in cis- $\mathrm{Cl}_{2}$ systems, see: (b) Barbasiewicz, M.; Szadkowska, A.; Bujok, R.; Grela, K., Structure and Activity Peculiarities of Ruthenium Quinoline and Quinoxaline Complexes: Novel Metathesis Catalysts. Organometallics 2006, 25, 3599-3604. (c) Ung, T.; Hejl, A.; Grubbs, R. H.; Schrodi, Y. Organometallics 2004, 23, 5399-5401. (d) Slugovc, C.; Perner, B.; Stelzer, F.; Mereiter, K. Organometallics 2004, 23, 3622-3626. (e) Ben-Asuly, A.; Tzur, E.; Diesendruck, C. E.; Sigalov, M.; Goldberg, I.; Lemcoff, N. G. Organometallics 2008, 27, 811-813. For a computational study, see: (f) Benitez, D.; Goddard, W. A., III, The Isomerization Equilibrium between Cis and Trans Chloride Ruthenium 
Olefin Metathesis Catalysts from Quantum Mechanics Calculations. J. Am. Chem. Soc. 2005, 127, 12218-12219.

(24) Ashworth, I. W.; Hillier, I. H.; Nelson, D. J.; Percy, J. M.; Vincent, M. A., Olefin Metathesis by Grubbs-Hoveyda Complexes: Computational and Experimental Studies of the Mechanism and SubstrateDependent Kinetics. ACS Catal. 2013, 3, 1929-1939.

(25) Also established in sterically congested first-generation catalysts of the Grubbs class is alkylidene deprotonation by bound aryloxide, liberating the phenol and generating a $\mathrm{Ru}$ carbyne. See: ref $19 \mathrm{c}$ and: Coalter, J. N.; Bollinger, J. C.; Eisenstein, O.; Caulton, K. G., R-Group Reversal of Isomer Stability for $\mathrm{RuH}(\mathrm{X}) \mathrm{L}_{2}(\mathrm{CCHR})$ vs. $\mathrm{Ru}(\mathrm{X}) \mathrm{L}_{2}\left(\mathrm{CCH}_{2} \mathrm{R}\right)$ : Access to Four-Coordinate Ruthenium Alkylidenes (Carbenes) and Alkylidynes (Carbynes). New J. Chem. 2000, 24, 925-927.

(26) Small, variable proportions of water may also be relevant. Formation of benzaldehyde was earlier reported in a mass spectrometric study in which GII was exposed to water, and was attributed to nucleophilic attack by water on the benzylidene carbon. See: Kim, M.; Eum, M. S.; Jin, M. Y.; Jun, K. W.; Lee, C. W.; Kuen, K. A.; Kim, C. H.; Chin, C. S., Reactions of Ruthenium Benzylidenes with $\mathrm{H} 2 \mathrm{O}$ to give Benzaldehyde and (Aqua)ruthenium complex. J. Organomet. Chem. 2004, $689,3535-3540$. While standard anhydrous conditions were employed in the present work, and water was not detected by ${ }^{1} \mathrm{H}$ NMR analysis, $\mathrm{H}-$ bonding to the hydroxide ligands is expected to promote water binding, and this could also shift the location of the water signal.

(27) Romero, P. E.; Piers, W. E., Mechanistic Studies on 14-Electron Ruthenacyclobutanes: Degenerate Exchange with Free Ethylene. J. Am. Chem. Soc. 2007, 129, 1698-1704.

(28) Nizovtsev, A. V.; Afanasiev, V. V.; Shutko, E. V.; Bespalova, N. B., Metathesis Catalysts Stability And Decomposition Pathway. NATO Sci. Ser. II 2007, 243, 125-135.

(29) Bailey, G. A.; Foscato, M.; Higman, C. S.; Day, C. S.; Jensen, V. R.; Fogg, D. E., Bimolecular Coupling as a Vector for Decomposition of Fast-Initiating Olefin Metathesis Catalysts. J. Am. Chem. Soc. 2018, 140, 6931-6944.

(30) Nelson, D. J.; Nolan, S. P., Hydroxide Complexes of the Late Transition Metals: Organometallic Chemistry and Catalysis. Coord. Chem. Rev. 2017, 353, 278-294.
(31) Roesky, H. W.; Singh, S.; Yusuff, K. K. M.; Maguire, J. A.; Hosmane, N. S., Organometallic Hydroxides of Transition Elements. Chem. Rev. 2006, 106, 3813-3843.

(32) We exclude the possibility of homocoupling of Ru-4, given the low concentration of this species anticipated at any time, and because the observation of only $50 \%$ of the arene "tag" in the organic products $\mathbf{D}$ and E/E' requires interception of $50 \%$ of the starting HII-OH via heterocoupling.

(33) For addition of $50 \%$ of the gas-phase entropy as a correction factor, see: (a) Wertz, D. H. Relationship between the Gas-Phase Entropies of Molecules and their Entropies of Solvation in Water and 1-Octanol. J. Am. Chem. Soc. 1980, 102, 5316-5322, and later: e.g., (b) Cooper, J.; Ziegler, T. A Density Functional Study of $\mathrm{S}_{\mathrm{N}} 2$ Substitution at SquarePlanar Platinum(II) Complexes. Inorg. Chem. 2002, 41, 6614-6622. Our choice to retain gas-phase entropies is validated by a recent study benchmarking this and other approximations against $a b$ initio molecular dynamics calculations. See: (c) Besora, M.; Vidossich, P.; Lledos, A.; Ujaque, G.; Maseras, F., Calculation of Reaction Free Energies in Solution: A Comparison of Current Approaches. J. Phys. Chem. A 2018, 122, 1392-1399. Even with the approximations built into this choice, an association constant of $>800$ is computed for the dimer, a value more than 10 orders of magnitude greater than that for ethylene binding at room temperature.

(34) Engel, J.; Smit, W.; Foscato, M.; Occhipinti, G.; Törnroos, K. W.; Jensen, V. R., Loss and Reformation of Ruthenium Alkylidene: Connecting Olefin Metathesis, Catalyst Deactivation, Regeneration, and Isomerization. J. Am. Chem. Soc. 2017, 139, 16609-16619.

(35) Leitao, E. M.; van der Eide, E. F.; Romero, P. E.; Piers, W. E.; McDonald, R., Kinetic and Thermodynamic Analysis of Processes Relevant to Initiation of Olefin Metathesis by Ruthenium Phosphonium Alkylidene Catalysts. J. Am. Chem. Soc. 2010, 132, 2784-2794.

(36) Carty, A. J.; MacLaughlin, S. A.; Taylor, N. J., $\mathrm{Ru}_{4}(\mathrm{CO})_{10}(\mathrm{C}=\mathrm{CHPri})(\mathrm{OH})\left(\mathrm{PPh}_{2}\right):$ A Tetranuclear Ruthenium Carbonyl Cluster with $\mu_{4}$-Vinylidene and Face-Bridging Hydroxo-Groups; X-Ray Crystal Structures Of $\mathrm{Ru}_{4}(\mathrm{CO})_{10}\left(\mathrm{C}=\mathrm{CHPr}{ }^{\mathrm{i}}\right)(\mathrm{OR})\left(\mathrm{PPh}_{2}\right)(\mathrm{R}=\mathrm{H}$ or Et $) . J$. Chem. Soc., Chem. Commun. 1981, 476-477.

(37) Hahn, J. E., Transition Metal Complexes Containing Bridging Alkylidene Ligands. In Progress in Inorganic Chemistry, Lippard, S. J., Ed. John Wiley \& Sons: Hoboken, NJ, 1984; Vol. 31, pp 205-264. 


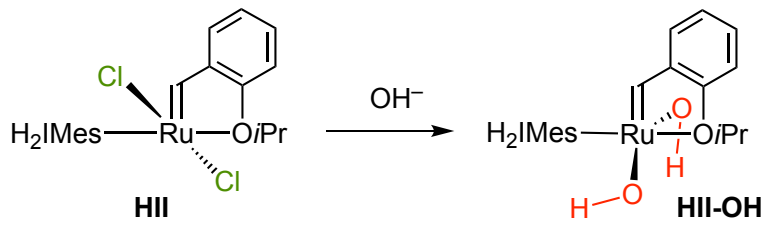

